페로브스카이트 태양전지의 최적 정공수송층 물질 및 구조 탐색 시뮬레이션

정지영 · 송동준 · 최지혜 · 정중희 · 홍기하*

한밭대학교 신소재공학과

\title{
Computational Design of Highly Efficient and Robust Hole Transport Layers in Perovskite Solar Cells
}

\author{
Jiyoung Jeong, Dongjun Song, Jihye Choe, Choong-Heui Chung, and Ki-Ha Hong*
}

Department of Materials Science and Engineering, Hanbat National University, Daejeon 34158, Republic of Korea

\begin{abstract}
We investigated the effects of materials and the film thickness of hole transport layers (HTLs) on inverted type perovskite solar cells using optics-charge transport coupled simulations. Power conversion efficiencies (PCEs), and the variations in efficiency induced by the film thickness dispersion, were intensively studied, to compare potential HTLs candidates like NiOx, PEDOT:PSS, CuSCN, and CuI. The optimum thickness of the solar cell layers differed based on the chosen combination of HTL and perovskite. It is suggested that the optoelectronic properties of HTLs like band gap, extinction coefficient, and refractive index can be used to determine the best ideal efficiencies, and sensitivity to process fluctuation. CuSCN showed the most promising behaviors, in that it can produce over-25\% PCEs, and the lowest efficiency dispersion for various HTL thickness conditions. The best performance by CuSCN can be ascribed to its having a proper refractive index with the perovskite layer, and wide band gap characteristic. $\mathrm{NiOx}$ and CuI showed PCEs comparable to the CuSCN, but their efficiencies were sensitive to the varying thickness of the HTL. PEDOT:PSS exhibited the lowest simulated PCEs due to its small band gap. Our study suggests the best HTL candidates for inverted type perovskite solar cells, and demonstrates the importance of sophisticated numerical material studies, and device design, when developing highly efficient and robust perovskite solar cells.
\end{abstract}

(Received April 30, 2019; Accepted June 10, 2019)

Keywords: perovskite solar cells, hole transport layers, simulation, optimization, inverted type

\section{1. 서 론}

금속계 할라이드 페로브스카이트 (metal-halide perovskites, $\mathrm{MHPs}$ )는 최근 들어 가장 많은 주목을 받고 있는 차세대 태양전지 소재라 할 수 있다. 2009년 일본의 Miyasaka 그룹이 처음으로 methylammonium tri-iodide( $\left.\mathrm{MAPbI}_{3}\right)$ 를 염료감응형 태양전지의 광흡수물질로 사용하여 $3 \%$ 대의 광전변환효율을 기록한 이후 [1], 폭발적인 효율개선속도를 보이면서 최근에는 $24 \%$ 이상의 공인 효율을 기록하여 박 막형 태양전지 후보군 중 가장 높은 효율을 기록하게 되었

- 정지영 - 송동준: 학사과정, 최지혜: 연구원, 정중희 · 홍기하: 교수 *Corresponding Author: Ki-Ha Hong

[Tel: +82-42-821-1238, E-mail: kiha.hong@hanbat.ac.kr]

Copyright (c) The Korean Institute of Metals and Materials
다 [2]. 이러한 급속도의 효율개선을 위해, 지난 9년여 동안 수 많은 연구자들은 소재 및 공정기술의 최적화와 태양전지 구조의 개선을 위해 다양한 노력을 경주해 왔다 [3-5].

역사적으로 찾기 힘들 정도로 빠른 효율의 개선속도를 보일 수 있는 원인을 찾기 위해, 최근 들어 다양한 실험, 측정 및 계산을 통해 $\mathrm{MHP}$ 재료의 독특한 성질을 규명하 고자 하는 시도가 계속되고 있다. 현재까지 밝혀진 바에 따르면 MHP 재료는 결함특성이 매우 독특하여 내재결함 에 의한 charge trapping이 발생하지 않는 것으로 알려졌 다 [6]. 또한 $\mathrm{MAPbI}_{3}$ 의 경우 Rashba 효과로 인해 소재 내부에서의 recombination이 억제되고 있다 [7]. 저렴한 용 액공정으로 제조하기 때문에 소재 내부에는 다양한 형태의 결함의 존재를 피할 수 없음에도 불구하고 이러한 MHP소 재의 특수성으로 인해 진공공정을 통해 제조되는 기존의 
박막형 태양전지와 경쟁할 수 있는 효율을 보여주고 있다 고 할 수 있다.

페로브스카이트 태양전지의 구조는 전하수송층을 적층하 는 순서에 따라, normal type (n-i-p) 과 inverted type (p-i-n) 으로 나눌 수 있다. 현재 최고효율의 태양전지는 ni-p 구조를 통해 구현되고 있는데, p-i-n 구조는 n-i-p 구조 에 비해 효율 측면에서는 약간 낮은 값을 보여주고 있으나, hysteresis 가 적게 발생하며 [8,9], $\mathrm{Si}$ 태양전지와 tandem 구조를 만들기에 용이하다는 장점으로 인해 지속적인 관심 을 받고 있다 [10,11]. Inverted type 태양전지에서는 정공 수송층이 빛을 흡수하는 방향에 존재하기 때문에, 정공수 송층(hole transport layers, HTLs) [12] 과 페로브스카이트층 을 동시에 최적화하는 것이 필수적이다. 현재 inverted type에 서 HTL로 많이 활용되는 물질로는 Nickel Oxide $\left(\mathrm{NiO}_{\mathrm{x}}\right)$ [13,14], Poly(3,4-ethylenedioxythiophene) Polystyrene Sulfonate (PEDOT:PSS) [8], Copper Thiocyanate (CuSCN) [15,16], Copper Iodide (CuI) [16] 를 들 수 있다. 이 들 각각의 HTL 물질들은 서로 다른 광전기적 물성을 갖고 있기 때문에 페로브스카이트와 같이 적층하였을 때 최적의 두께 및 최고기대효율이 달라질 수 있다. 용액공정으로 박 막을 제조하는 페로브스카이트 태양전지의 특성상, 소자의 구조 및 소재의 특성은 제조하는 연구자의 숙련도와 공정 방법에 의해 많은 편차를 갖게 된다. 이러한 실험상의 편 차로 인해 최고 효율을 도출할 수 있는 박막물질 및 구조 의 결정은 실험적인 방법만으로는 어렵다고 할 수 있다.

반도체의 전하수송을 해석하는 계산방법은 반도체소재로 부터 이끌어 낼 수 있는 이상적인 효율을 예측할 수 있다. 금속계 할라이드 페로브스카이트 물질 역시 빛을 흡수는 물론 전하수송이 가능한 반도체 물질임이 밝혀진 이후 [4], 반도체 태양전지를 해석하는 데 사용가능한 시뮬레이션 기 법을 활용한 연구가 활발히 진행되었다. Liu 등이 2014년 에 발표한 planar-type 페로브스카이트 태양전지의 기대효 율 예측에 대한 계산논문 [17]이 발표된 이후, 태양전지의 거동에 미치는 소재의 영향을 파악하고 구조를 최적화하는 방법에 대한 발표가 계속되어 왔다 [18-20].

페로브스카이트 태양전지의 최적 전하수송층을 도출하기 위해서는, 다양한 후보군 물질에 대하여, 태양전지 박막층 의 두께를 최적화하는 과정을 거쳐야 한다. 각 정공수송층 은 각기 다른 전자구조와 굴절률을 갖고 있기 때문에, 달 성가능한 최고효율과 최적의 구조는 각 물질에 따라 다를 수밖에 없다. 종래의 시뮬레이션 연구들은 물질의 변화는 고려하지 않고, 구조의 변화만을 고려하거나 박막 두께는 고정한 채로 물질의 변화만을 탐구하였기 때문에, 페로브
스카이트 태양전지의 최고성능을 위한 재료의 도출에는 어 려움이 있었다. 그리고, 구조변화에 따른 산포는 종래연구 에서 고려되지 않고 있는데, 용액공정으로 제조하는 페로 브스카이트 태양전지의 특성상 산포의 억제는 가장 중요한 설계인자라 할 수 있다.

따라서, 본 연구에서는 페로브스카이트 태양전지를 구성 하는 정공수송층의 물질과 구조 두 가지 측면을 모두 고려 한 시뮬레이션을 통해, 산포를 최대로 억제하며 최고의 성 능을 낼 수 있는 정공수송층 물질과 구조를 제안하고자 한 다. 우선 계산에 활용된 수학적 방법을 간략히 소개한다. 그 다음 전하수송층 물질의 변화와 태양전지의 거동양상의 상관관계를 분석하여 정공수송층 물질의 영향을 고찰한다. 다음으로 박막의 두께의 변화가 효율 및 소자 특성에 미치 는 영향을 물질별로 도출하여 최적의 물질과 구조를 도출 하고, 이를 바탕으로 각 정공전달 물질이 태양전지의 효율 의 산포에 기여하는 양을 정량화하여 도출하고자 한다.

\section{2. 계산 방법}

본 연구에 사용한 inverted type의 페로브스카이트 태양 전지구조의 개략도를 그림 1(a)에 도시하였다. 빛이 들어오 는 쪽에 해당하는 ITO의 두께는 $200 \mathrm{~nm}$ 로 설정하였고, 페 로브스카이트와 정공수송층 (hole transport layer, HTL)의 두께는 $100 \mathrm{~nm} \sim 600 \mathrm{~nm}, 20 \mathrm{~nm} \sim 220 \mathrm{~nm}$ 로 다양하게 변화시켜가면서 계산을 수행했다. 전자수송층 (electron transport layer, ETL) 과 top-electrode는 $\mathrm{PCBM}$ 과 $\mathrm{Ag}$ 를 기준물질로 사용하였으며, 점검 결과 이 두 층의 두께는 inverted type 태양전지의 거동에 미치는 영향이 미미하였 다. 페로브스카이트는 가장 널리 사용되고 있는 $\mathrm{MAPbI}_{3}$ 를 해석 대상으로 하였으며 물성은 Liu 등이 발표한 이전 논문에 있는 물성치를 사용하였고 [17], $\mathrm{MAPbI}_{3}$ 의 complex refractive index는 Xing 등이 발표한 논문의 값 을 추출하여 사용하였다 [21].

태양전지의 엄밀한 해석을 위해서는 광학계산과 [22] 반 도체수송모델을 결합한 해석을 수행해야 한다. 본 연구에 서는 이와 같은 광학-반도체수송 결합계산을 위하여 Synopsys사의 Synopsys-TCAD [23]를 활용하여 계산을 수행하였다. 시뮬레이션 과정을 그림 1(b)에 나타내었다. 빛의 조사에 의한 전하의 생성은 전자소자의 전하의 움직 임에 비해 상대적으로 빠르기 때문에, 본 계산에서는 광학 계산을 우선적으로 수행하고 여기서 도출된 광생성 전류분 을 반도체 수송모델의 source 항에 더해서 계산을 수행하 는 계층적 연결해석 방법을 사용한다. 조금 더 상세하게 
기술하면 다음과 같다. 소자를 구성하고 있는 물질의 구조 및 파장에 따른 굴절률, 흡수계수를 물질상수값으로 입력 하여 transfer matrix method (TMM)를 사용한 광학계산 을 수행한다. $\mathrm{TMM}$ 계산을 통해 태양전지구조에서 각 위 치별 반사율, 투과율, 흡수율이 도출되며, 주어진 태양광 스 펙트럼 값에 흡수율을 곱하여 각 계산격자점 별로 전하의 생성분을 계산할 수 있다. 이렇게 도출된 광전하 생성분을 반도체 수송모델의 전하생성항에 더해 주게 된다. 반도체 수송모델로는 drift-diffusion (DD) 모델을 사용하였다 [24]. DD 모델에서는 전자와 정공의 연속방정식 (식 (1)과 (2)) 과 전위차에 대한 Poisson 식 (식(3))을 동시에 수렴 시켜서 전위값과 전류값을 도출하게 되는데, 이 때 앞선 광학계산에서 도출된 광전하 생성항과, 반도체 수송모델의 재결합모델 (direct recombination, indirect recombination, SRH recombination model)을 결합하여 해석을 수행하게 된다.

$$
\begin{aligned}
& \frac{\partial n}{\partial t}=\frac{1}{q} \nabla \cdot J_{n}+U_{n} \\
& \frac{\partial p}{\partial t}=\frac{1}{q} \nabla \cdot J_{p}+U_{p} \\
& \nabla \cdot(\varepsilon \nabla \psi)=-q\left(p-n+N_{D}-N_{A}\right)
\end{aligned}
$$

위 식에서 $\mathrm{n}, \mathrm{p}, \mathrm{q}$ 는 각각 전자, 정공의 농도와 전하의 기준치를 의미하며, $U_{n}$ 과 $U_{p}$ 는 전자와 정공의 생성-재결 합 분율이다. $N_{D}$ 와 $N_{A}$ 는 이온화되어 있는 donor와 acceptor의 농도 값이며 $J_{n}$ 과 $J_{p}$ 는 전자와 정공의 전류밀 도를 의미하며, 식 (4) 와 (5)에 나타난 것처럼 전하의 drift와 diffusion 항으로 구성되어 있다.

$$
\begin{aligned}
& J_{n}=q n(x) \mu_{n} E(x)+q D_{n} \frac{d n}{d x} \\
& J_{p}=q p(x) \mu_{p} E(x)-q D_{p} \frac{d p}{d x}
\end{aligned}
$$

$E$ 는 전기장의 세기이며, $\mu$ 과 $D$ 는 각각 전하의 이동 도와 확산계수를 각각 의미한다. $\mathrm{DDM}$ 을 사용한 반도체 시뮬레이션을 수행할 때 이종접합간 계면에서는 conduction band $(\mathrm{CB})$ 와 valence band $(\mathrm{VB})$ 의 배열이 매우 중요하다 [25]. 본 연구에서 고려한 4가지 $\mathrm{HTL}$ 물질의 $\mathrm{CB}$ 및 $\mathrm{VB}$ 의 배열을 그림 $1(\mathrm{c})$ 에 도시하였다. HTL로 기능하기 위해 서는 정공의 수송은 원활하게 일어나면서 전자에 대해서는 에너지장벽의 역할을 수행해야 하는데, 그림에 도시된 것 처럼 4가지 물질 모두 해당 기능을 수행하는 데 지장이 없을 것으로 예상된다. 계산에 사용된 $\mathrm{NiO}_{\mathrm{x}}, \mathrm{PEDOT}: \mathrm{PSS}$, (a)
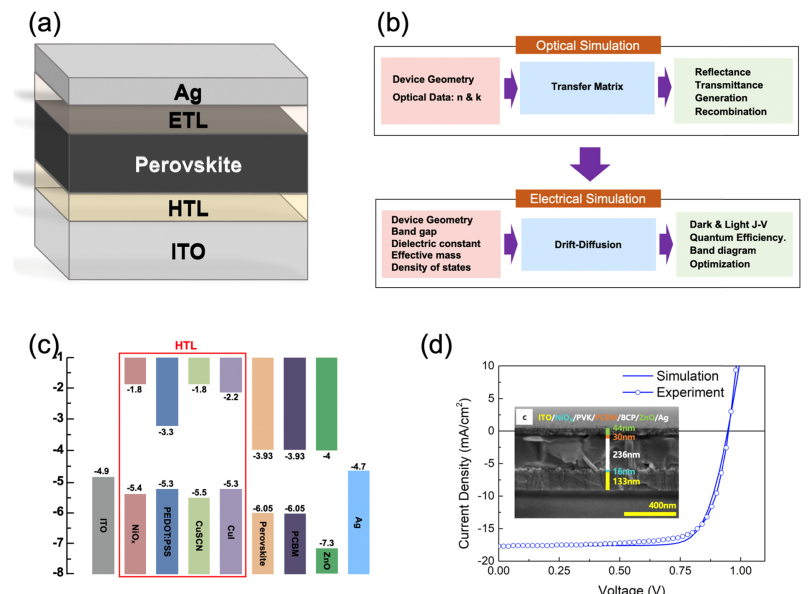

(d)

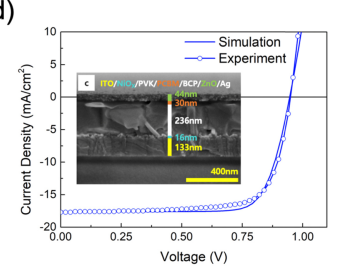

Fig. 1. (a) Device structures for the simulation of perovskite solar cells. (b) Flow map of a two-step simulation. (c) Conduction band and valence band alignments of ITO, HTL, MAPbI 3 , ETL, and Ag. Band alignments of HTL layers are represented in the red rectangle. (d) Comparison of current-voltage characteristic between experimental and computational studies. Inset shows the crosssectional scanning electron microscopic images of fabricated perovskite solar cells which were made in our laboratory.

$\mathrm{CuSCN}$ 과 $\mathrm{CuI}$ 의 물성을 표 1 에 정리하였다. 개발된 계산 모듈의 적용가능성을 검증하기 위해 본 그룹이 제조한 페 로브스카이트 태양전지의 구조에 적용하여 직렬저항과 결 함 농도의 변화를 통해 실험결과를 반영할 수 있는 결과가 도출됨을 확인하였다. (그림 $1(\mathrm{~d})$ )

\section{3. 결과 및 고찰}

\section{1. 정공수송층 물질과 태양전지성능의 상관관계}

정공수송층이 태양전지 거동에 미치는 영향을 분석하기 위하여 동일한 태양전지구조를 형성하고, 정공수송물질을 달리하여 태양전지 성능평가의 주요인자인, 광전변환효율 (power conversion efficiency, PCE), fill factor (FF), 단 락전류 (short circuit current, $\mathrm{J}_{\mathrm{SC}}$ ), 그리고 개방전압 (open circuit voltage, $\mathrm{V}_{\mathrm{OC}}$ ) 를 계산한 결과를 표 2에 나 타내었다. 기준 조건으로 페로브스카이트의 두께를 350 $\mathrm{nm}$, 정공수송층의 두께 $30 \mathrm{~nm}$ 로 설정하여 계산을 수행 하였다. 효율을 보면 $\mathrm{NiO}_{\mathrm{x}}$ 가 $23.02 \%$ 로 가장 높았고, 그 다음으로 $\mathrm{CuSCN}$ 이 $22.86 \%, \mathrm{CuI}$ 가 $22.45 \%$, 마지막으로 PEDOT:PSS가 $21.9 \%$ 로 가장 낮았다. 비교의 편의를 위해 $\mathrm{CuSCN}$ 의 값을 기준으로 하여 각 태양전지의 성능값을 normalize하여 그림 2에 도시하였다. $\mathrm{V}_{\mathrm{OC}}$ 는 $1.21 \mathrm{~V}$ 로 동일한 수준이었고, $\mathrm{FF}$ 또한 약 $86 \%$ 로 거의 차이가 없었 다. 가장 차이가 큰 요인은 $\mathrm{J}_{\mathrm{SC}}$ 였다. $\mathrm{NiO}_{\mathrm{x}}$ 와 $\mathrm{CuSCN}$, 
Table 1. Materials properties used in simulations for considered HTLs. Refractive index and extinction coefficient are the value at $550 \mathrm{~nm}$ wavelength. Variations with regard to wavelength can be found in cited references.

\begin{tabular}{l|c|c|c|c}
\hline \multicolumn{1}{c|}{ Parameters and units } & $\mathrm{NiO}_{\mathrm{x}}$ & PEDOT : PSS & $\mathrm{CuSCN}$ & $\mathrm{CuI}$ \\
\hline Dielectric constant & $11.75[26]$ & $3.9[27]$ & $5.1[28]$ & $4.58[29]$ \\
\hline Band Gap (eV) & $3.6[26]$ & $2[30]$ & $3.7[31]$ & $3.1[32]$ \\
\hline Electron Affinity(eV) & $1.8[26]$ & $3.3[30]$ & $1.8[31]$ & $2.2[32]$ \\
\hline Hole Mobility $\left(\mathrm{cm}^{2} / \mathrm{V} / \mathrm{s}\right)$ & $2.0 \times 10^{-1}[26]$ & $0.1[33]$ & $0.1[34]$ & $43.9[35]$ \\
\hline Effective conduction Band Density $\left(\mathrm{cm}^{-3}\right)$ & $\left(1 \times 10^{18}\right)[36]$ & $\left(1 \times 10^{18}\right)$ & $\left(2.2 \times 10^{19}\right)[37]$ & $\left(2.8 \times 10^{19}\right)[37]$ \\
\hline Effective Valence Band Density $\left(\mathrm{cm}^{-3}\right)$ & $\left(1 \times 10^{18}\right)[36]$ & $\left(1 \times 10^{18}\right)$ & $\left(1.8 \times 10^{18}\right)[37]$ & $\left(1 \times 10^{19}\right)[37]$ \\
\hline Refractive index(@ 550 nm) & $2.25[38]$ & $1.51[39]$ & $1.91[40]$ & $2.35[29]$ \\
\hline Extinction coefficient $(@ 550 \mathrm{~nm})$ & $0.0083[38]$ & $0.0082[39]$ & $0.0018[40]$ & $0.11[29]$ \\
\hline
\end{tabular}

(a)
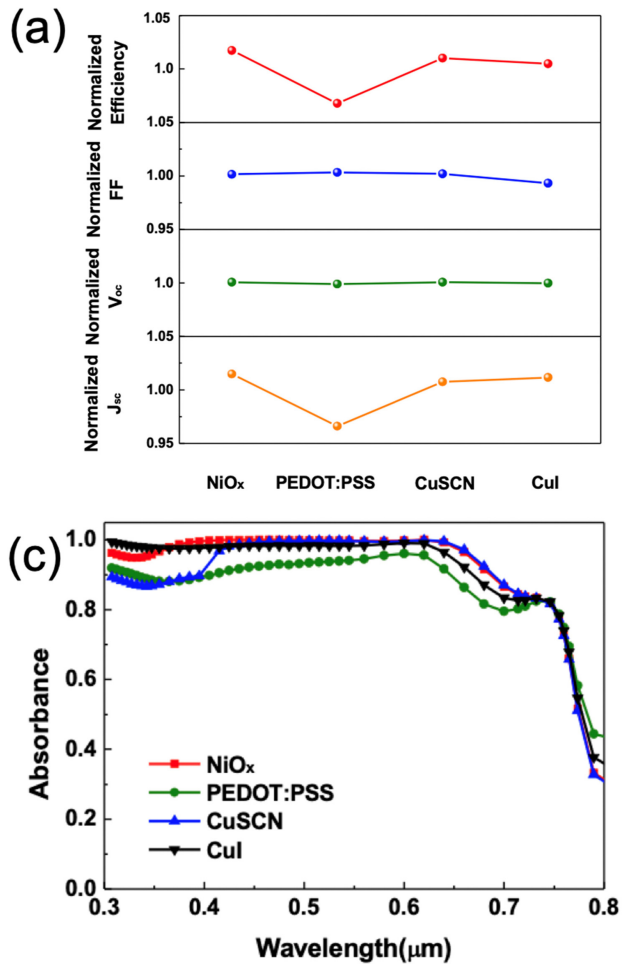

(b)
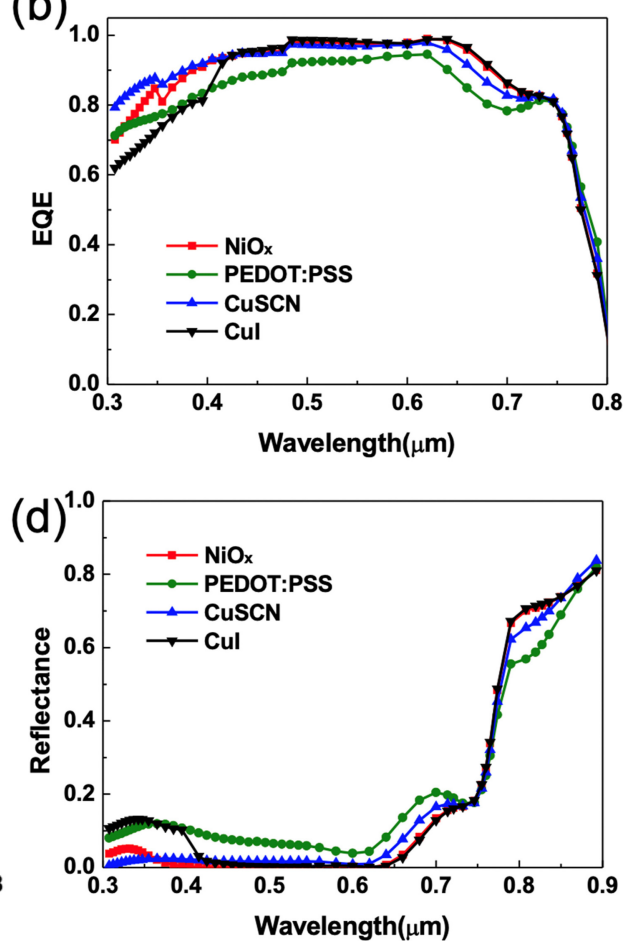

Fig. 2. Normalized efficiencies, fill factors $(\mathrm{FF})$, short circuit currents $\left(\mathrm{J}_{\mathrm{SC}}\right)$, and open circuit voltages $\left(\mathrm{V}_{\mathrm{OC}}\right)$ for the same device structures $\left(\mathrm{t}_{\text {perov. }}=350 \mathrm{~nm}, \mathrm{t}_{\mathrm{HTL}}=30 \mathrm{~nm}\right)$. (b) External quantum efficiencies $(\mathrm{EQE}),(\mathrm{c})$ absorbance, and (d) reflectance of perovskite solar cells where HTL consists of $\mathrm{NiO}_{\mathrm{x}}$, PEDOT:PSS, CuSCN, and CuI respectively.

$\mathrm{CuI}$ 는 $21.85 \sim 22.01 \mathrm{~mA} / \mathrm{cm}^{2}$ 으로 비슷한 수준이었지만 PEDOT:PSS는 $20.95 \mathrm{~mA} / \mathrm{cm}^{2}$ 으로 가장 낮은 값을 나타내 었다. $\mathrm{J}_{\mathrm{SC}}$ 차이의 원인을 분석하기 위해 external quantum efficiency (EQE, 그림 2(b))와 absorbance (그림 2(c)), reflectance (그림 2(d)) 를 살펴보았다. 먼저 $\mathrm{EQE}$ 를 보면, $\mathrm{CuSCN}$ 과 $\mathrm{NiO}_{\mathrm{x}}$ 가 전파장에 걸쳐 높은 $\mathrm{EQE}$ 를 보였다. $\mathrm{NiO}_{\mathrm{x}}$ 는 단파장에서 $\mathrm{CuSCN}$ 보다 $10 \%$ 낮았지만 장파장에서 는 더 높은 $\mathrm{EQE}$ 를 가진다. $\mathrm{CuI}$ 는 비교적 높은 $\mathrm{EQE}$ 를 나타내고 있으나 단파장에서 낮은 값을 보이고 있다. Absorbance 결과 (그림 2(c)) 와 reflectance (그림 2(d))
를 참조해보면, $\mathrm{CuI}$ 는 단파장에서 $\mathrm{NiO}_{\mathrm{x}}$ 에 비해 비교적 높 은 반사율을 보이며 $\mathrm{CuSCN}$ 은 단파장에서 상대적으로 낮 은 흡수율을 보인다. PEDOT:PSS는 전파장에 걸쳐 낮은 $\mathrm{EQE}$ 를 보이는데, 흡수와 반사 모든 측면에서 상대적으로 열위를 보이고 있다. 표 2를 확인해 보면 PEDOT:PSS는 다른 HTL 물질에 비해 낮은 밴드갭을 갖고 있음을 알 수 있다. 이로 인해 단파장에서 가장 낮은 흡수율을 보일 수 밖에 없는데다가, refractive index가 perovskite와 가장 큰 차이를 보여주기 때문에 반사도도 증가하게 되어, 고려한 물질 중 가장 낮은 기대효율을 기록하게 되었다. 고정된 구 
Table 2. Calculated efficiencies, fill factors (FF), short circuit currents $\left(\mathrm{J}_{\mathrm{SC}}\right)$, and open circuit voltages $\left(\mathrm{V}_{\mathrm{OC}}\right)$ for the same device structures $\left(\mathrm{t}_{\text {perov. }}=350 \mathrm{~nm}, \mathrm{t}_{\mathrm{HTL}}=30 \mathrm{~nm}\right)$.

\begin{tabular}{c|c|c|c|c}
\hline $\mathrm{HTL}$ & $\mathrm{J}_{\mathrm{sc}}\left(\mathrm{mA} / \mathrm{cm}^{2}\right)$ & $\mathrm{V}_{\mathrm{oc}}(\mathrm{V})$ & $\mathrm{FF}(\%)$ & $\begin{array}{c}\text { Efficiency } \\
(\%)\end{array}$ \\
\hline $\mathrm{NiO}_{\mathrm{x}}$ & 22.0 & 1.21 & 86.3 & 23.0 \\
\hline $\mathrm{PEDOT}$ & 21.0 & 1.21 & 86.5 & 22.0 \\
\hline $\mathrm{CuSCN}$ & 21.9 & 1.21 & 86.3 & 22.9 \\
\hline $\mathrm{CuI}$ & 21.9 & 1.21 & 85.6 & 22.7 \\
\hline
\end{tabular}

조변수에 대한 계산을 통해 광학물성 측면에서 가장 기대 효율이 낮은 물질은 PEDOT:PSS 임을 도출할 수 있었다.

\section{2. 정공수송층 구조의 영향}

페로브스카이트의 구조변수를 고정한 채로 HTL 물질을 변화시켜 가면서 수행한 계산을 통해 PEDOT:PSS를 제외 한 나머지 물질들이 비교적 동등한 효율을 보일 수 있음을 제시할 수 있었다. 그렇지만 이러한 광전변환효율은 구조 변수의 영향을 고려해야만 하기 때문에, 각 물질별로 두께 의 변화가 미치는 영향을 평가해야만 한다. 이를 위해 페 로브스카이트의 두께와 $\mathrm{HTL}$ 의 두께를 각각 $100 \mathrm{~nm}$ $600 \mathrm{~nm}$ 와 $20 \mathrm{~nm} \sim 220 \mathrm{~nm}$ 범위에서 변화시켜가면서 효율 의 변화를 관찰하였다 (그림 3). 최고효율의 도출을 위해 이상적인 페로브스카이트층을 가정하였기 때문에, 두께가 증가할 수록 광전변환효율이 증가하게 된다. 앞서 언급했 듯이, 이상적인 태양전지 구조의 경우, 동일 페로브스카이 트 두께 조건에서는 $\mathrm{J}_{\mathrm{SC}}$ 가 HTL 변화에 가장 민감한 인자 로 작동하게 된다. 이에 대한 비교 평가를 위해 두께의 변 화에 따른 $\mathrm{EQE}$ 의 변화를 선별하여 광전변환효율과 함께 도시하였다 (그림 $3 \mathrm{~d}$ 의 우측 단). 그림 3 에서 주목해야하 는 부분은 HTL의 두께에 따른 효율변화의 양상이다. 다른 물질에 비해 $\mathrm{CuSCN}$ 을 사용했을 때 가장 넓은 범위에 걸 쳐 최고효율의 도출이 가능함을 확인할 수 있으며, 앞선 단일 조건계산에서 확인한 것처럼, PEDOT:PSS의 기대효 율이 가장 낮게 나타났다.

$\mathrm{NiO}_{\mathrm{x}}$ 는 20-80 nm의 얇은 두께 범위와 페로브스카이트가 $500 \mathrm{~nm}$ 이상일 때 고효율을 얻을 수 있다 (그림 3(a)). 그렇지만 $\mathrm{NiO}_{\mathrm{x}}$ 의 두께의 변화에 따라서 기대효율이 많은 영향을 받는 것을 볼 수 있다. 이는 $\mathrm{EQE}$ 에서도 확인할 수 있었다. $\mathrm{NiO}_{x}$ 의 두께가 증가할수록 단파장 영역에서 급 속하게 $\mathrm{EQE}$ 가 감소하는 것을 볼 수 있다 (그림 3(b)). $\mathrm{NiO}_{\mathrm{x}}$ 는 단파장에서 흡수계수가 높아 두께가 두꺼워질수록 더 많은 빛을 흡수하여서 $\mathrm{EQE}$ 가 감소하게 된다. 따라서 $\mathrm{NiO}_{\mathrm{x}}$ 를 $\mathrm{HTL}$ 로 활용할 경우 되도록 얇고 균일한 박막을
만드는 것이 필수적이라 할 수 있다. 반면에 $\mathrm{CuSCN}$ 은 $\mathrm{NiO}_{\mathrm{x}}$ 보다 두꺼운 두께에서도 고효율을 얻을 수 있을 것으 로 보이며 HTL 두께에 따른 편차도 크게 나타나지 않는 다 (그림 $3(\mathrm{c})) . \mathrm{CuSCN}$ 의 경우 굴절률 측면에서 페로브스 카이트의 광학물성 조합이 가장 우수하여, 박막 구조의 편 차에도 가장 신뢰도 높은 결과를 보여줄 수 있는 것으로 판단된다. $\mathrm{EQE}$ 계산결과 (그림 3(d)) 를 보면 $\mathrm{CuSCN}$ 은 단파장 영역에서도 두께 변화에 따라 차이가 거의 발생하 지 않는 것을 확인할 수 있다. PEDOT:PSS는 밴드갭이 $2 \mathrm{eV}$ 로 다른 물질들에 비해 매우 작아 장파장의 빛이 페로 브스카이트까지 도달하지 못한다. 따라서 $\mathrm{J}_{\mathrm{SC}}$ 가 현저히 낮 아져 효율에 악영향을 미친다. 그림 3(e) 에서 확인할 수 있듯이 두꺼운 페로브스카이트 박막에 최소 두께의 PEDOT:PSS를 사용하더라도 기대효율은 상대적으로 낮게 나타난다. 기대효율의 크기뿐만 아니라 박막 두께에 따른 편차도 심하게 나타나는데, $\mathrm{EQE}$ 를 확인해 보면 전파장대 에 걸쳐 상대적으로 낮은 값을 보일 뿐 아니라 두께의 변 화에 대해 민감하게 변하고 있는 것을 확인할 수 있다 (그 림 3(f)). 마지막으로 $\mathrm{CuI}$ 의 경우 PEDOT:PSS에 비해서는 우수한 특성을 보이나, $\mathrm{NiO}_{\mathrm{x}}$ 와 $\mathrm{CuSCN}$ 에 비해서는 이상 적 효율이 낮은 것을 확인할 수 있다 (그림 $3(\mathrm{~g})$ ). 앞서 언급한 것처럼 단파장에서 $\mathrm{CuI}$ 의 반사도가 다른 물질에 비 해 상대적으로 높게 나타나게 되는데, 이로 인해 $\mathrm{EQE}$ 값 이 단파장 영역대에서 낮게 나타나게 되는 것이 원인으로 사료된다 (그림 3(h)).

\section{3 정공수송층 두께의 영향}

위에 도시한 결과에서 동일한 페로브스카이트 두께에서, $\mathrm{HTL}$ 의 구조변화를 도시하면 앞서 언급한 HTL 물질의 변 화가 미치는 산포의 영향을 좀 더 쉽게 확인할 수 있다. 그림 4(a)는 페로브스카이트의 두께를 $400 \mathrm{~nm}$ 로 고정한 채, $\mathrm{HTL}$ 의 두께의 변화가 효율에 미치는 영향을 도시한 것이 다. 두께의 변화에 따라서 광흡수율의 변화가 발생하기 때 문에 특정한 두께에서 최적의 효율을 달성하게 됨을 보여 준다. PEDOT:PSS는 가장 급격하게 효율의 저하가 발생하 면서 두께 변화에 가장 민감한 물질임을 보여주며, $\mathrm{NiO}_{\mathrm{x}}$, $\mathrm{CuSCN}, \mathrm{CuI}$ 는 제각각 최고 효율을 달성할 수 있는 두 께가 다르다는 것을 확인할 수 있다. 그리고 두께에 따른 편차가 $\mathrm{CuSCN}$ 이 가장 적은 것을 확인할 수 있다. 이러한 편차를 정량적으로 확인하기 위해 앞서 도출한 결과에 대 한 표준편차를 도출하여 그림 4(b)에 도시하였다. 저비용 페로브스카이트 태양전지는 주로 용액공정을 통해 제조된 다. 이럴 경우 각 박막층의 두께는 $\mathrm{nm}$ 수준으로 평탄하게 
(a)

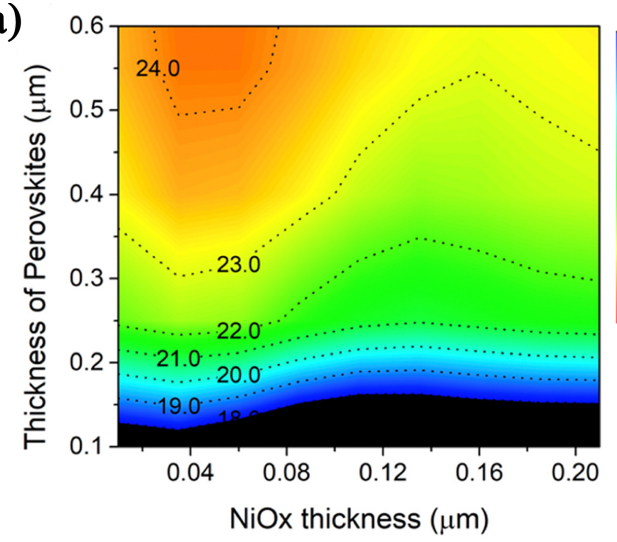

(c)

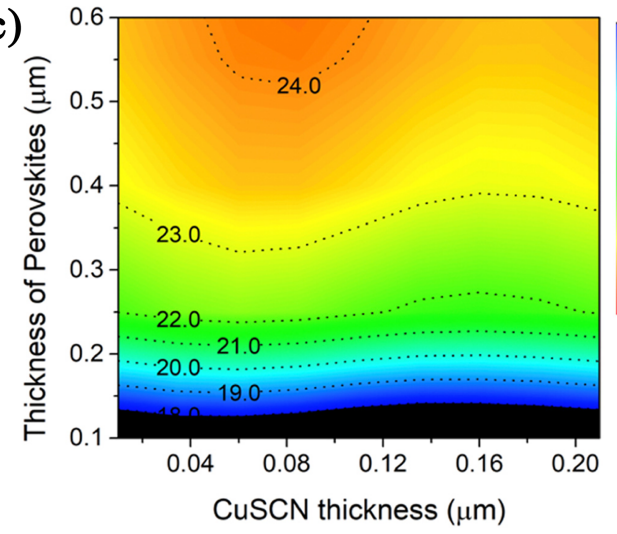

(e)

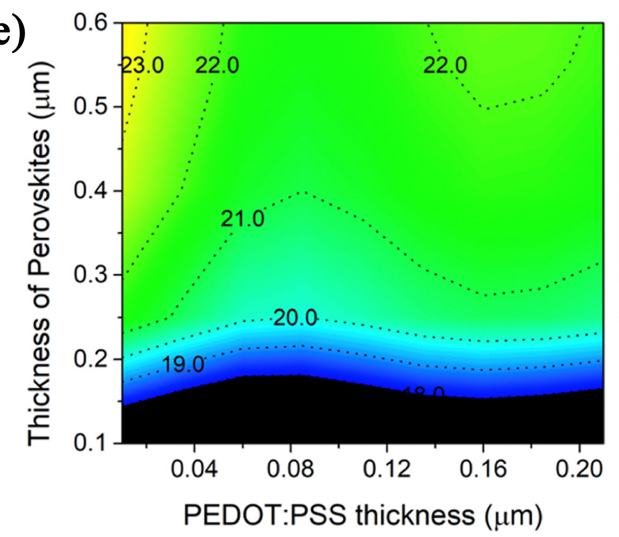

(g)

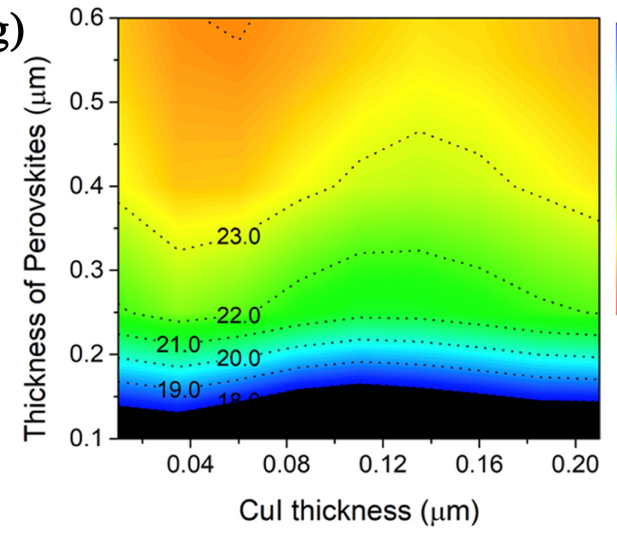

(b)
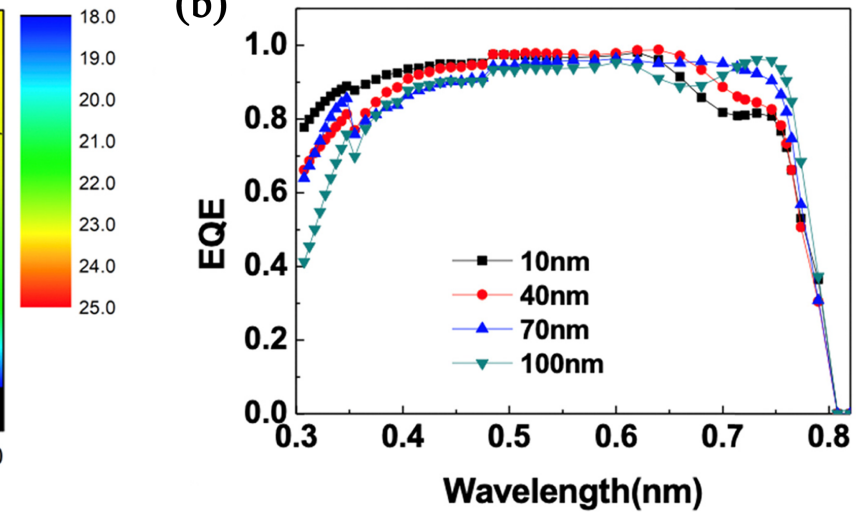

(d)

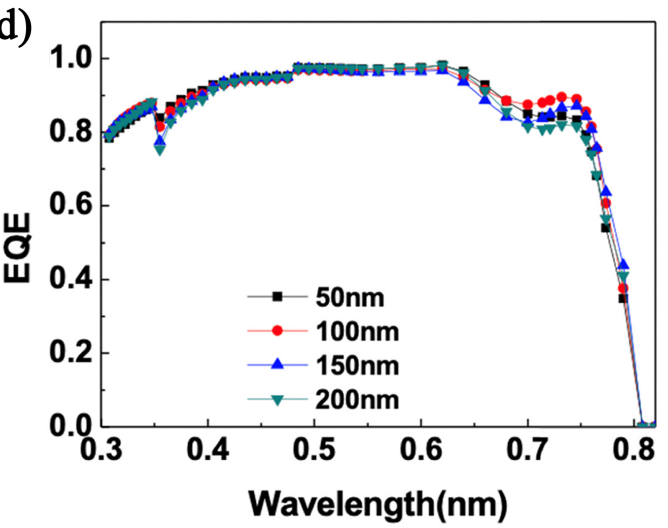

(f)

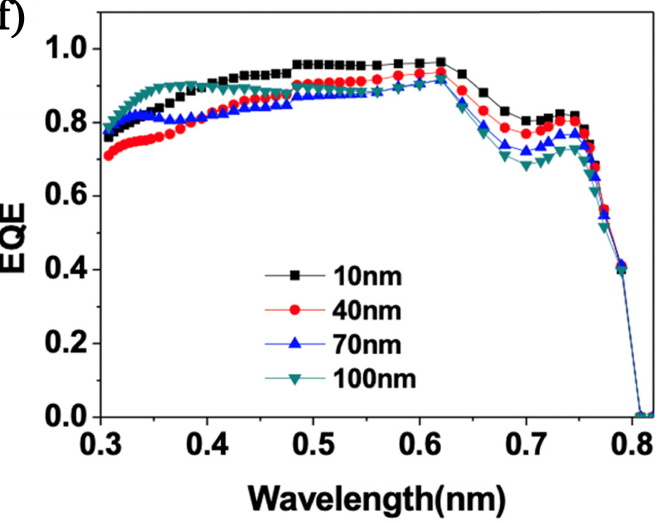

(h)

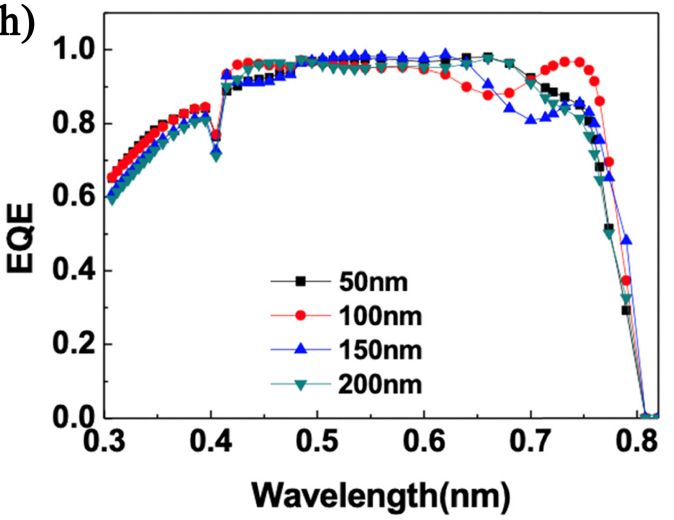

Fig. 3. Computed power conversion efficiencies with regard to the thickness of HTLs and perovskites (left contour figures) and external quantum efficiencies at various HTL thicknesses (right line figures) of $\mathrm{NiO}_{\mathrm{x}}(\mathrm{a}, \mathrm{b}), \mathrm{CuSCN}(\mathrm{c}, \mathrm{d}), \mathrm{PEDOT}$ :PSS (e,f), and CuI (g,h). 


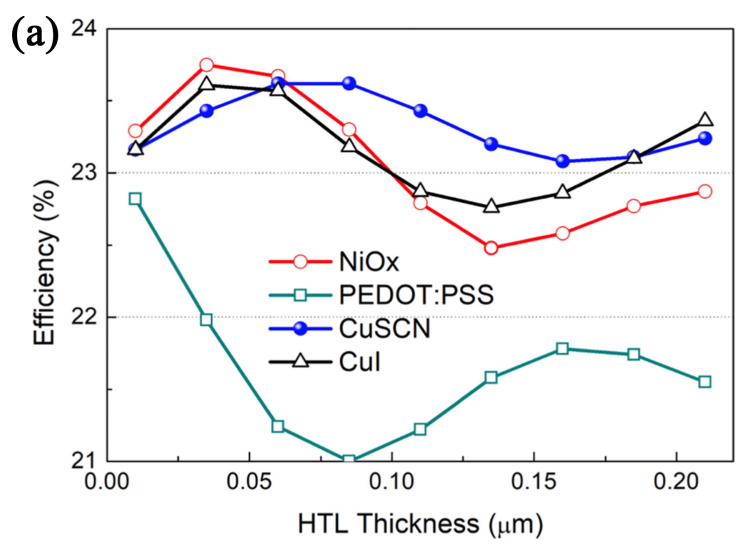

(b) 0.6

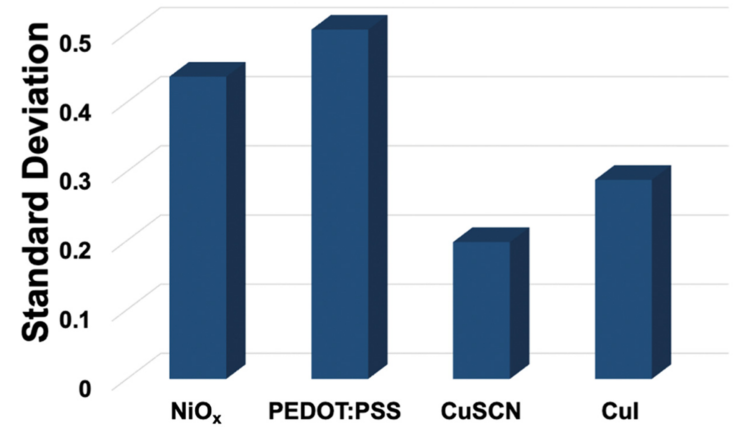

Fig. 4. (a) The effects of the HTL thickness on the power conversion efficiency and (b) standard deviations for $\mathrm{NiO}_{x}$, PEDOT:PSS, CuSCN, and CuI when the thickness of perovskites is fixed at $400 \mathrm{~nm}$.

나타나기는 매우 어렵다 [41]. 이러한 내재적인 문제의 극 복을 위해서는 태양전지를 구성하는 박막의 두께 편차와 효율의 연관성이 적은 것이 유리하다. 특히나 모듈화 하였 을 때 태양전지의 효율은 가장 낮은 태양전지에 의해서 결 정되기 때문에, 최고효율의 가능성이 있는 물질의 선택도 중요하지만 효율의 편차를 최대로 억제할 수 있는 물질의 선택도 중요하다. 페로브스카이트의 박막 두께와의 최적 조 합을 찾게 되면 달성 가능한 효율은 $25 \%$ 이상이 될 수 있다는 그림 3 의 결과를 바탕으로 하여, 공정변수의 민감 도가 가장 적은 $\mathrm{HTL}$ 을 선택한다면 $\mathrm{CuSCN}$ 이 가장 유리 할 것으로 판단할 수 있다.

\section{4. 결 론}

광학계산과 반도체수송모델 계산을 연결해석하는 수치해 석 기법을 활용하여 inverted type 페로브스카이트 태양전 지의 최적 정공수송층 물질과 구조 탐색을 수행하였다. $\mathrm{NiO}_{\mathrm{x}}, \mathrm{PEDOT}: \mathrm{PSS}, \mathrm{CuSCN}, \mathrm{CuI}$ 를 정공수송층 물질로
선정하여 페로브스카이트의 두께와 정공수송층의 두께변화 가 태양전지의 성능에 미치는 영향을 비교 평가하였다. 광 전변환효율과 $\mathrm{HTL}$ 의 두께 편차에 의한 산포를 주요 평가 인자로 하여 계산결과를 분석하였다. 고려한 물질 중 $\mathrm{CuSCN}$ 이 효율과 산포 두 가지 측면에서 우수한 물질이라 는 것을 밝힐 수 있었고, $\mathrm{CuI}$ 와 $\mathrm{NiO}_{x}$ 는 효율 측면에서는 $\mathrm{CuSCN}$ 과 동등하나, $\mathrm{HTL}$ 층 두께의 편차에 따른 효율 변 화가 비교적 심하게 발생하여 효율값의 산포 측면에서 $\mathrm{CuSCN}$ 에 비해 불리할 것임을 제시하였다. PEDOT:PSS는 상대적으로 좁은 밴드갭과 높은 반사율로 인해 가장 낮은 기대효율을 보여주고 있으며 산포측면에서도 우수하지 못 한 결과를 보였다.

PEDOT:PSS를 제외한 나머지 HTL 물질을 차용할 경우, $\mathrm{MAPbI}_{3}$ 물질의 최적화와 HTL 물질의 두께 최적화 과정 을 거치면 기대효율은 모두 $25 \%$ 이상이 될 것으로 예측 되었다. 현재 고효율 태양전지의 소재로 많이 채택되고 있 는 formamidinium lead tri-iodides $\left(\mathrm{FAPbI}_{3}\right)$ 물질을 사용 할 경우, 흡수가능한 파장대가 더 넓어지는 만큼 광전변환 효율은 본 연구에서 예측된 값보다 더 높은 값을 얻을 수 있게 될 것이다. 본 연구를 통해 도출된 결과를 보면, 최 적의 소재와 소자구조는 물질별 광학물성과 전자구조에 의 해 매번 다르게 도출되는 만큼, 향후 본 연구의 방법론을 확장 적용하여 다양한 페로브스카이트 구조와 전하수송층 설계에 활용하고자 한다.

\section{감사의 글}

본 연구는 정부의 재원으로 한국연구재단의 지원을 받아 수행되었습니다 (NRF-2018R1A2B6007888). 계산 소프트 웨어인 Synopsys $\mathrm{TCAD}$ 는 $\mathrm{IDEC}$ 의 지원으로 사용하였습 니다.

\section{REFERENCES}

1. A. Kojima, K. Teshima, Y. Shirai, and T. Miyasaka, J. Am. Chem. Soc. 131, 6050 (2009).

2. Best Research-Cell Efficiencies Chart, 〈https://www.nrel.gov/ pv/assets/pdfs/best-research-cell-efficiencies-190416.pdf $\rangle$

3. H.-S. Kim, C.-R. Lee, J.-H. Im, K.-B. Lee, T. Moehl, A. Marchioro, S.-J. Moon, R. Humphry-Baker, J.-H. Yum, J. E. Moser, M. Grätzel, and N.-G. Park, Sci. Rep. 2, 591 (2012).

4. M. M. Lee, J. Teuscher, T. Miyasaka, T. N. Murakami, and H. J. Snaith, Science 338, 643 (2012).

5. N. J. Jeon, J. H. Noh, Y. C. Kim, W. S. Yang, S. Ryu, S. I. 
Seok, Nat. Mater. 13, 897 (2014).

6. J. Kim, S.-H. Lee, J. H. Lee, and K.-H. Hong, J. Phys. Chem. Lett. 5, 1312 (2014).

7. M. Kepenekian and J. Even, J. Phys. Chem. Lett. 8, 3362 (2017).

8. J. H. Heo, H. J. Han, D. Kim, T. K. Ahn, and S. H. Im, Energy Environ. Sci. 8, 1602 (2015).

9. H. B. Kim, H. Choi, J. Jeong, S. Kim, B. Walker, S. Song, and J. Y. Kim, Nanoscale 6, 6679 (2014).

10. K. A. Bush, A. F. Palmstrom, Z. J. Yu, M. Boccard, R. Cheacharoen, J. P. Mailoa, D. P. McMeekin, R. L. Z. Hoye, C. D. Bailie, T. Leijtens, I. M. Peters, M. C. Minichetti, N. Rolston, R. Prasanna, S. Sofia, D. Harwood, W. Ma, F. Moghadam, H. J. Snaith, T. Buonassisi, Z. C. Holman, S. F. Bent, and M. D. McGehee, Nat. Energy 2, 17009 (2017).

11. G. E. Eperon, T. Leijtens, K. A. Bush, R. Prasanna, T. Green, J. T. W. Wang, D. P. McMeekin, G. Volonakis, R. L. Milot, R. May, A. Palmstrom, D. J. Slotcavage, R. A. Belisle, J. B. Patel, E. S. Parrott, R. J. Sutton, W. Ma, F. Moghadam, B. Conings, A. Babayigit, H. G. Boyen, S. Bent, F. Giustino, L. M. Herz, M. B. Johnston, M. D. McGehee, and H. J. Snaith, Science 354, 861 (2016).

12. K. Kim, T. Park, and O. Song, Korean J. Met. Mater. 56, 321 (2018).

13. W. Nie, H. Tsai, J.-C. Blancon, F. Liu, C. C. Stoumpos, B. Traoré, M. Kepenekian, O. Durand, C. Katan, S. Tretiak, J. Crochet, P. M. Ajayan, M. Kanatzidis, J. Even, and A. D. Mohite, Adv. Mater. 30, 1703879 (2017).

14. S. Seo, I. J. Park, M. Kim, S. Lee, C. Bae, H. S. Jung, N.-G. Park, J. Y. Kim, and H. Shin, Nanoscale 8, 11403 (2016).

15. S. Ye, W. Sun, Y. Li, W. Yan, H. Peng, Z. Bian, Z. Liu, and C. Huang, Nano Lett. 15, 3723 (2015).

16. Q. Xi, G. Gao, H. Zhou, Y. Zhao, C. Wu, L. Wang, P. Guo, and J. Xu, Nanoscale 9, 6136 (2017).

17. F. Liu, J. Zhu, J. Wei, Y. Li, M. Lv, S. Yang, B. Zhang, J. Yao, and S. Dai, Appl. Phys. Lett. 104, 253508 (2014).

18. F. Azri, A. Meftah, N. Sengouga, and A. Meftah, Solar Energy 181, 372 (2019).

19. L. Huang, X. Sun, C. Li, R. Xu, J. Xu, Y. Du, Y. Wu, J. Ni, H. Cai, J. Li, Z. Hu, and J. Zhang, Sol. Energ. Mat. Sol. 157, 1038 (2016).

20. R. Pandey and R. Chaujar, Superlattice. Microst. 100, 656 (2016).

21. G. Xing, N. Mathews, S. S. Lim, N. Yantara, X. Liu, D. Sabba, M. Grätzel, S. Mhaisalkar, and T. C. Sum, Nat. Mater. 13, 476 (2014).
22. I. Y. Hwang, J.-S. Ha, and S.-W. Ryu, Korean J. Met. Mater. 55, 813 (2017).

23. Synopsys Inc. Synopsys TCAD Sentaurus Device User's Manual, Synopsys Inc., Tech. Rep. Release I-2013.12 (2013).

24. S. M. Sze and K. K. Ng, Physics of Semiconductor Devices, John wiley \& sons (2006).

25. T. Minemoto and M. Murata, Sol. Energ. Mat. Sol. 133, 8 (2015).

26. E. Karimi and S. M. B. Ghorashi, J. Nanophoton. 11, 032510 (2017).

27. F.-C. Chen, C.-W. Chu, J. He, Y. Yang, and J.-L. Lin, Appl. Phys. Lett. 85, 3295 (2004).

28. P. Pattanasattayavong, A. D. Mottram, F. Yan, and T. D. Anthopoulos, Adv. Funct. Mater. 25, 6802 (2015).

29. C. Authors, E.O.T.V.I. 17B-22A-41B, in:, II-VI and I-VII Compounds; Semimagnetic Compounds, Springer, Berlin, Heidelberg, Berlin/Heidelberg (1999).

30. S. Ahn, K. Yabumoto, Y. Jeong, and K. Akagi, Polym. Chem. 5, 6977 (2014).

31. M. Li, K. Gao, X. Wan, Q. Zhang, B. Kan, R. Xia, F. Liu, X. Yang, H. Feng, W. Ni, Y. Wang, J. Peng, H. Zhang, Z. Liang, H.-L. Yip, X. Peng, Y. Cao, and Y. Chen, Nat. Photon. 11, 85 (2016).

32. C.-C. Chueh, C.-Z. Li, and A. K. Y. Jen, Energy Environ. Sci. 8, 1160 (2015).

33. B. Li, L. Wang, B. Kang, P. Wang, and Y. Qiu, Sol. Energ. Mat. Sol. 90, 549 (2006).

34. I. Sullivan, B. Zoellner, and P. A. Maggard, Chem. Mater. 28, 5999 (2016).

35. N. Yamada, R. Ino, Y. Ninomiya, Chem. Mater. 28, 4971 (2016).

36. Y. Wang, Z. Xia, Y. Liu, and H. Zhou, In 2015 IEEE 42nd Photovoltaic Specialist Conference (PVSC) 2015 Jun 14 (pp. 1-4). IEEE (2015).

37. M. I. Hossain, F. H. Alharbi, and N. Tabet, Solar Energy 120, 370 (2015).

38. N. Kitazawa, Y. Watanabe, and Y. Nakamura, J. Mater. Sci 37, 3585 (2002).

39. C.-W. Chen, S.-Y. Hsiao, C.-Y. Chen, H.-W. Kang, Z.-Y. Huang, and H.-W. Lin, J. Mater. Chem. A 3, 9152 (2015).

40. P. Pattanasattayavong, G. O. N. Ndjawa, K. Zhao, K. W. Chou, N. Yaacobi-Gross, B. C. O'Regan, A. Amassian, and T. D. Anthopoulos, Chem. Commun. 49, 4154 (2013).

41. M. Liu, M. B. Johnston, and H. J. Snaith, Nature 501, 395 (2013). 